\title{
Reliability of system identification technique in super high-rise building
}

\author{
Ayumi Ikeda, Kohei Fujita and Izuru Takewaki* \\ Department of Architecture and Architectural Engineering, Kyoto University, Kyoto, Japan
}

A smart physical-parameter-based system identification (SI) method has been proposed in the previous paper (Ikeda et al., 2014a). This method deals with time-variant nonparametric identification of natural frequencies and modal damping ratios using AutoRegressive eXogenous (ARX) models and has been applied to high-rise buildings during the 2011 off the Pacific coast of Tohoku earthquake. In this perspective article, the current state of knowledge in this class of SI methods is explained briefly, and the reliability of this smart method is discussed through the comparison with the result by a more confident technique.

\section{OPEN ACCESS}

Edited by:

Solomon Tesfamariam,

The University of British Columbia,

Canada

Reviewed by:

Xinzheng Lu,

Tsinghua University, China

Marie-José Nollet,

École de Technologie Supérieure,

Canada

*Correspondence:

Izuru Takewaki,

Department of Architecture and Architectural Engineering, Kyoto

University, Nishikyo,

Kyoto 615-8540, Japan

takewaki@archi.kyoto-u.ac.jp

Specialty section:

This article was submitted to

Earthquake Engineering,

a section of the journal

Frontiers in Built Environment

Received: 08 June 2015 Accepted: 08 July 2015

Published: 21 July 2015

Citation:

Ikeda A, Fujita K and Takewaki I

(2015) Reliability of system identification technique in super high-rise building.

Front. Built Environ. 1:11. doi: 10.3389/fbuil.2015.00011
Keywords: system identification, super high-rise building, time-varying identification, reliability of system identification, ARX model, noise reduction

System identification (SI) techniques are very popular and widely used worldwide. SI techniques may be classified into a modal-parameter SI and a physical-parameter SI (Housner et al., 1997; Takewaki et al., 2011a). SI techniques are usually used as tools for damage detection after extreme natural disasters (e.g., earthquakes) or methods for the investigation of accuracy of models utilized in the design stage.

In damage detection, the monitoring of healthy states is inevitable. This procedure requires a large amount of preparing work before damage occurs, and it is necessary to gather data for the healthy state. Unless we know the healthy state, it is not possible to know whether the state after an event is healthy or damaged. Although it may be possible to monitor the structural behavior in real time, it will require a large amount of cost. As far as a shear building model and a shear-bending model are concerned, the recording at limited floors (not real-time monitoring) may be realistic and possible (Kuwabara et al., 2013; Minami et al., 2013). These methods are based on a pioneering nonparametric approach (Udwadia et al., 1978) and the subsequent realistic extensions (Takewaki and Nakamura, 2000, 2005, 2009; Takewaki et al., 2011a). Kuwabara et al. (2013) developed a physicalparameter damage detection technique of a shear-bending model for the first time and Minami et al. (2013) opened the door for the physical-parameter SI techniques of a shear-bending model. On the other hand, some approaches using full data and a great deal of repeated calculations have been proposed for shear buildings (Zhang and Johnson, 2012, 2013a,b; Johnson and Wojtkiewicz, 2014).

For the reduction of influence of noise, some approaches using ARX models have been developed (Takewaki and Nakamura, 2009; Takewaki et al., 2011a; Minami et al., 2013; Ikeda et al., 2014a). Especially the method by Takewaki and Nakamura (2009), Takewaki et al. (2011a) deals with timevariant non-parametric identification of natural frequencies and modal damping ratios using ARX models. The method has been applied successfully to an actual base-isolated building (Takewaki and Nakamura, 2009; Takewaki et al., 2011a) and has also been applied to high-rise buildings during 2011 off the Pacific coast of Tohoku earthquake (Minami et al., 2013; Ikeda et al., 2014a).

Figure 1 shows a super high-rise steel building of 55 stories at Osaka bay area which was the highest in the western Japan at that time and was constructed in 1995 just after the Hyogoken-Nanbu earthquake (Kobe earthquake) (Takewaki et al., 2011b; Celebi et al., 2014). An important recording 

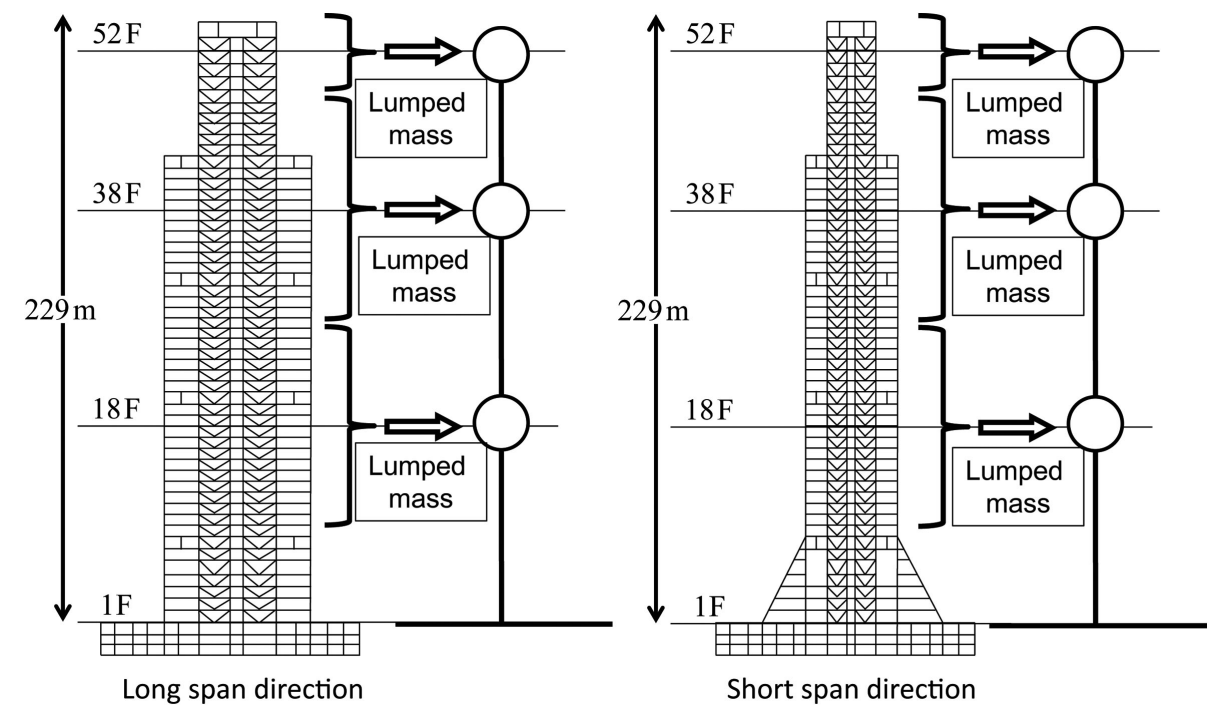

FIGURE 1 | Super high-rise building at Osaka bay area
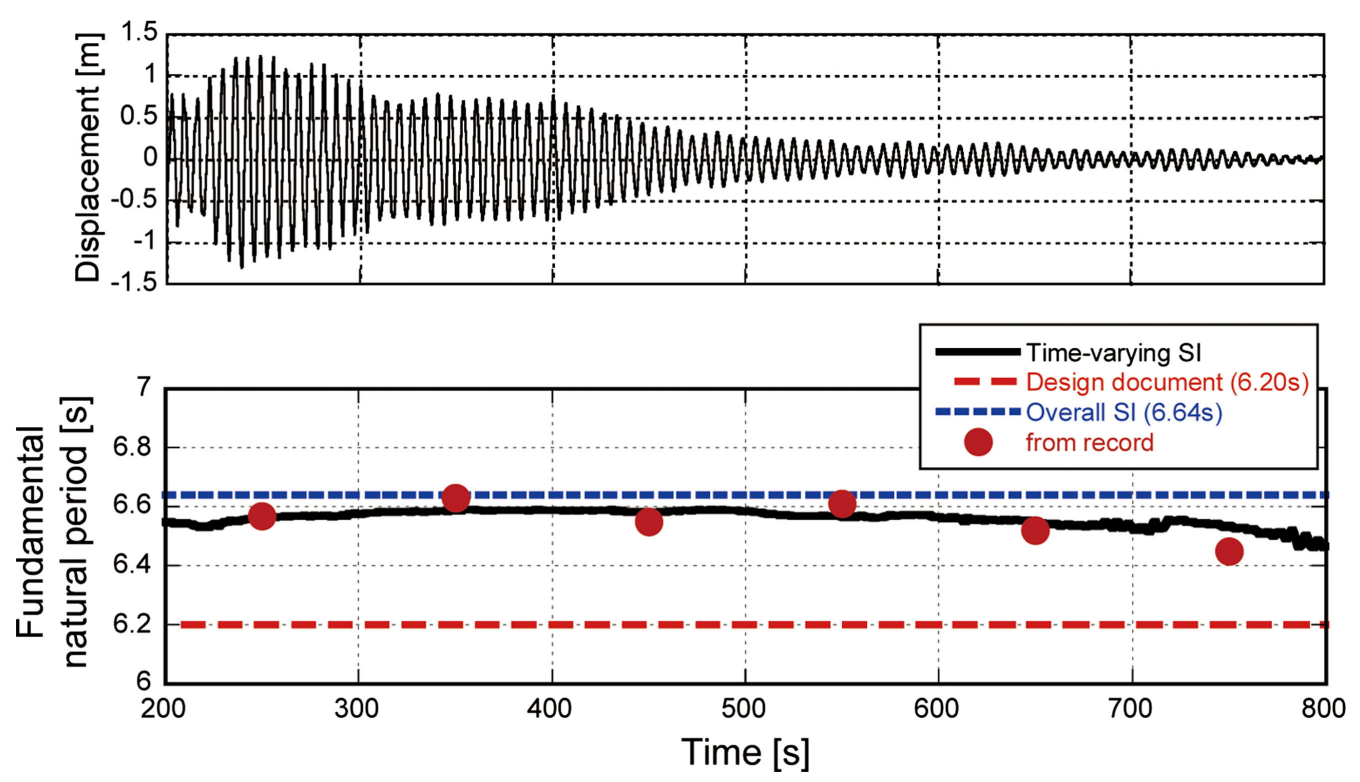

FIGURE 2 | Top-story displacement and fundamental natural period of super high-rise building at Osaka bay area (short-span direction): accuracy investigation through comparison with data from records.

was made in this building during 2011 off the Pacific coast of Tohoku earthquake. The building height is $256 \mathrm{~m}$. The fundamental natural period is $5.8 \mathrm{~s}$ in the long-span direction and $5.3 \mathrm{~s}$ in the short-span direction. This building was shaken severely even though Osaka is located far from the epicenter (about $800 \mathrm{~km}$ ) and the Japan Meteorological Agency (JMA) instrumental intensity was 3 in Osaka. It is remarkable that the level of velocity response spectra of ground motions observed here (first floor) is almost the same as that at the Shinjuku station (K-NET) in Tokyo and the top-story displacement are about $1.4 \mathrm{~m}$ (short-span direction) and $0.9 \mathrm{~m}$ (long-span direction). It was understood that this building was just resonant with the surface ground fundamental natural period of about $6.4 \mathrm{~s}[4 \times$ (depth of deep ground)/(shear wave velocity $)=4 \times 1.6(\mathrm{~km}) / 1.0(\mathrm{~km} / \mathrm{s})]$ and the fundamental-mode vibration component was predominant.

A smart physical-parameter based SI has been conducted in this building (Minami et al., 2013; Ikeda et al., 2014a). The outline of the time-varying identification, called the moving-window batch least-squares method, has been explained in the reference (Ikeda et al., 2014a). The duration of $30 \mathrm{~s}$ was used as the evaluation time for the batch least-squares method and this process was repeated by moving the window progressively by $1 \mathrm{~s}$. The top-story 
displacement and the time-varying fundamental natural period of this building (short-span direction) have been identified (Ikeda et al., 2014a), which was evaluated by the moving-window batch least-squares method. The time-varying SI indicates the result by the moving-window batch least-squares method and the overall SI means the result, which uses the batch least-squares method in the whole duration. The time dependency of the fundamental natural period may result from its amplitude dependence and reported slight damage to some non-structural elements (ceiling walls, etc.). The accuracy of the method can be confirmed by the comparison with data from record shown in Figure 2. The six points in Figure $\mathbf{2}$ have been plotted by investigating the period between zero-crossing points in the top-story displacement. As pointed out before, the fundamental vibration mode was predominant in this building during the 2011 Tohoku earthquake, and the top-story displacement was governed mostly by the fundamental vibration mode. The good

\section{References}

Celebi, M., Okawa, I., Kashima, T., Koyama, S., and Iiba, M. (2014). Response of a tall building far from the epicenter of the 11 March 2011 M9.0 great east Japan earthquake and aftershocks. Struct. Des. Tall Spec. Build. 23, 427-441. doi:10.1002/tal.1047

Fujita, K., Ikeda, A., and Takewaki, I. (2015). Application of story-wise shear building identification method to actual ambient vibration. Front. Built Environ. 1:2. doi:10.3389/fbuil.2015.00002

Housner, G. W., Bergman, L. A., Caughey, T. K., Chassiakos, A. G., Claus, R. O., Masri, S. F., et al. (1997). Special issue, structural control: past, present, and future. J. Eng. Mech. 123, 897-971. doi:10.1061/(ASCE)0733-9399(1997)123: 9(897)

Ikeda, A., Minami, Y., Fujita, K., and Takewaki, I. (2014a). Smart system identification of super high-rise buildings using limited vibration data during the 2011 Tohoku earthquake. Int. J. High Rise Build. 3, 255-271.

Ikeda, A., Fujita, K., and Takewaki, I. (2014b). Story-wise system identification of shear building using ambient vibration data and ARX model. Earthq. Struct. 7, 1093-1118. doi:10.12989/eas.2014.7.6.1093

Johnson, E., and Wojtkiewicz, S. (2014). Efficient sensitivity analysis of structures with local modifications. II: transfer functions and spectral densities. J. Eng. Mech. 140, 04014068. doi:10.1061/(ASCE)EM.1943-7889.0000769

Kuwabara, M., Yoshitomi, S., and Takewaki, I. (2013). A new approach to system identification and damage detection of high-rise buildings. Struct. Control Health Monit. 20, 703-727. doi:10.1002/stc.1486

Minami, Y., Yoshitomi, S., and Takewaki, I. (2013). System identification of super high-rise buildings using limited vibration data during the 2011 Tohoku (Japan) earthquake. Struct. Control Health Monit. 20, 1317-1338.

Takewaki, I., and Nakamura, M. (2000). Stiffness-damping simultaneous identification using limited earthquake records. Earthq. Eng. Struct. Dyn. 29, 1219-1238. doi:10.1002/1096-9845(200008)29:8<1219::AID-EQE968>3.0.CO;2-X

Takewaki, I., and Nakamura, M. (2005). Stiffness-damping simultaneous identification under limited observation. J. Eng. Mech. 131, 1027-1035. doi:10.1061/ (ASCE)0733-9399(2005)131:10(1027) correspondence of the fundamental natural period between the time-varying SI, and the data analysis using the top-story displacement demonstrates the reliability of the time-varying SI (Ikeda et al., 2014a).

The reduction of influence of noise may be a central issue in the field of SI. The applicability to ambient vibration data and the development of more reliable methods should be investigated in the future (Ikeda et al., 2014b; Fujita et al., 2015).

\section{Acknowledgments}

The use of ground motion records from Building Research Institute of Japan and Osaka Prefectural Office is appreciated. Part of the present work is supported by the Grant-in-Aid for Scientific Research of Japan Society for the Promotion of Science (Nos. 24246095 and 15H04079). This support is greatly appreciated.

Takewaki, I., and Nakamura, M. (2009). Temporal variation of modal properties of a base-isolated building during an earthquake. J. Zhejiang Univ. Sci. A 11, 1-8. doi:10.1631/jzus.A0900462

Takewaki, I., Nakamura, M., and Yoshitomi, S. (2011a). System Identification for Structural Health Monitoring. Southampton: WIT Press.

Takewaki, I., Murakami, S., Fujita, K., Yoshitomi, S., and Tsuji, M. (2011b). The 2011 off the Pacific coast of Tohoku earthquake and response of high-rise buildings under long-period ground motions. Soil Dyn. Earthq. Eng. 31, 1511-1528. doi:10.1016/j.soildyn.2011.06.001

Udwadia, F., Sharma, D., and Shah, C. (1978). Uniqueness of damping and stiffness distributions in the identification of soil and structural systems. J. Appl Mech. 45, 181-187. doi:10.1115/1.3424224

Zhang, D., and Johnson, E. (2012). Substructure identification for shear structures: cross power spectral density method. Smart Mater. Struct. 21, 055006. doi:10. 1088/0964-1726/21/5/055006

Zhang, D., and Johnson, E. (2013a). Substructure identification for shear structures I: substructure identification method. Struct. Control Health Monit. 20, 804-820. doi:10.1002/stc. 1497

Zhang, D., and Johnson, E. (2013b). Substructure identification for shear structures with nonstationary structural responses. J. Eng. Mech. 139, 1769-1779. doi:10. 1061/(ASCE)EM.1943-7889.0000626

Conflict of Interest Statement: The authors declare that the research was conducted in the absence of any commercial or financial relationships that could be construed as a potential conflict of interest.

Copyright (c) 2015 Ikeda, Fujita and Takewaki. This is an open-access article distributed under the terms of the Creative Commons Attribution License (CC $B Y)$. The use, distribution or reproduction in other forums is permitted, provided the original author(s) or licensor are credited and that the original publication in this journal is cited, in accordance with accepted academic practice. No use, distribution or reproduction is permitted which does not comply with these terms. 